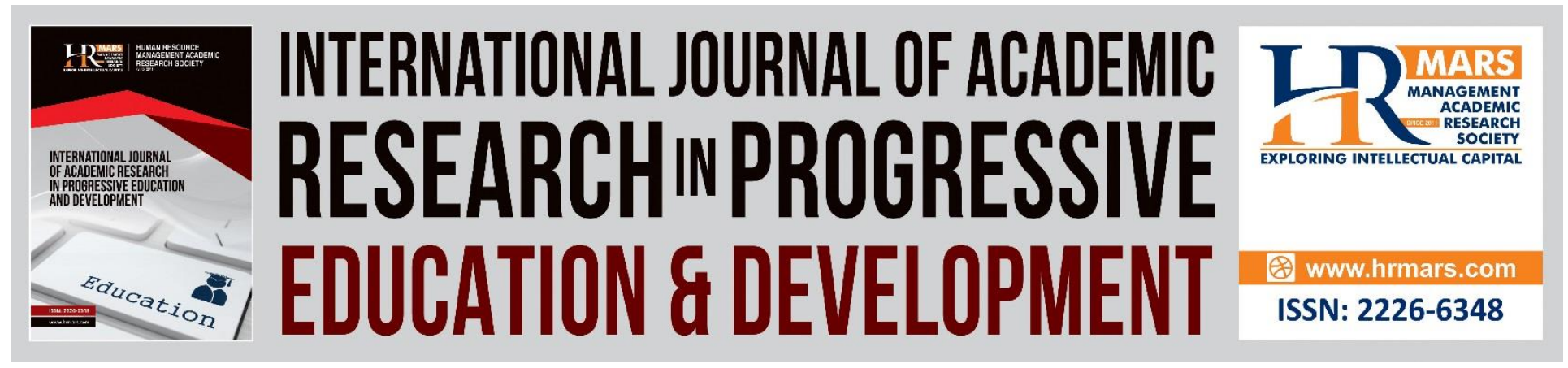

\title{
Determining Content Validity Instruments Shura Elements among Islamic Teachers in Primary Schools
}

Noor Azimah Surip, Khadijah Abdul Razak \& Ab. Halim Tamuri

To Link this Article: http://dx.doi.org/10.6007/IJARPED/v8-i4/6912

DOI:10.6007/IJARPED/v8-i4/6912

Received: 19 September 2019, Revised: 30 November 2019, Accepted: 11 December 2019

Published Online: 31 December 2019

In-Text Citation: (Surip et al., 2019)

To Cite this Article: Surip, N. A., Razak, K. A., \& Tamuri, A. H. (2019). Determining Content Validity Instruments Shura elements among Islamic Teachers in Primary Schools. International Journal of Academic Research in Progressive Education \& Development, 8(4), 1120-1131.

Copyright: (C) 2019 The Author(s)

Published by Human Resource Management Academic Research Society (www.hrmars.com)

This article is published under the Creative Commons Attribution (CC BY 4.0) license. Anyone may reproduce, distribute, translate and create derivative works of this article (for both commercial and non-commercial purposes), subject to full attribution to the original publication and authors. The full terms of this license may be seen at: http://creativecommons.org/licences/by/4.0/legalcode

\section{Vol. 8(4) 2019, Pg. 1120 - 1131}

Full Terms \& Conditions of access and use can be found at http://hrmars.com/index.php/pages/detail/publication-ethics 


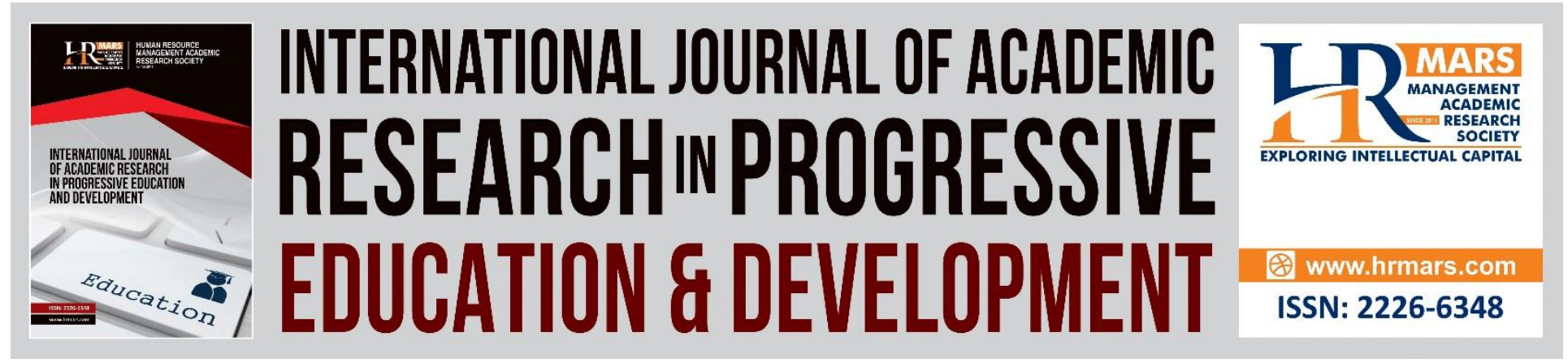

\title{
Determining Content Validity Instruments Shura Elements among Islamic Teachers in Primary Schools
}

\author{
Noor Azimah Surip, Khadijah Abdul Razak \& Ab. Halim Tamuri \\ Faculty of Education, National University of Malaysia.
}

\begin{abstract}
The purpose of this study was to measure the content validity by expert panel instruments shura elements among Islamic teachers in primary schools. This study was conducted to study the content validity of the shura instrument through two-step process namely development and judgment. In the first step, the domain determination and instrumentation. While the second step, the content validity ratio and content validation index were performed. Suggestions of expert panel and item impact scores are used to examine the instrument face validity. A total of eight expert panels which consist of five professional experts in the field and three experts who served in the primary school field were appointed as instrument approval panels. The findings show that $(\mathrm{N}=8, \mathrm{CVR}=0.75, \mathrm{CVI}=\geq 0.8)$ and 48 items were remained. The findings also clarify the origin and definition of content verification, content verification methods, the role of validity of content in legitimate arguments, and unresolved issues in content validation. Therefore, this version of instruments shura possesses desirable validity and reliability indices. The scale seems to measure specific aspects of quality in shura and suitable to be used as a measuring tool for the related future studies.

Keywords: Content Validity, shura, Islamic Teachers, Content Validity Ratio (CVR), Expert Panel.

\section{Introduction}

Content validity was designed and developed by rationale analysts for testing and evaluation of contents by qualified experts in the domain (Allen \& Yen, 2002). It refers to the extent to which a measure represents all facets of a given construct (Lawshe, 1975) to ensure that every item contained in the instruments which represent each domain is required and can be evaluated (Anastasi \& Urbina, 1997; Kerlinger, 1986; Rahayah, 2008) and verified (Miller, Loveler \& McIntire, 2013). This analysis process aims to provide assurance on the validity of the content which is a tool that is hoped to be used in other studies (Frank-Stromberg \& Olsen, 2004. Content validity is very important to ensure high quality and reliable measurement (Polit, Beck \& Owen, 2007. Thus, a set of specific standards such as the CVR should be undertaken to determine the validity of all of those items.
\end{abstract}




\section{Literature Review}

Shura is an Arabic word for consultation. The Quran and the Prophet Muhammad (pbuh) encourage Muslims to make decisions in their everyday affairs through consultations with those who will be affected by the decisions made (Esposito, 2003). Al-Buraey (1985) has defined shura as a management process or a tool used to achieve a collective decision. Azhary (1992) has also provided the meaning of shura which is a forum for exchanging ideas and insights, including making recommendations to resolve an issue before making a decision. This clearly demonstrates the importance of shura in the sight of Allah SWT and has proven that the practice is highly relevant in any forms of management in our lives. This shura practice is clearly emphasized through a verse in surah ali-Imran 3:159 which says "consult them in the matter. And when you have decided, then rely upon to Allah".

Based on the adaptation of Ibn Taimiyah's thoughts on shura, PDS model (Affandi, 1982) and literature review, a few important elements in shura that need to be analysed have been identified. In this aspect, the elements of shura to be measured are (1) understanding (tafahum), (2) cooperation (ta'awun), (3) tolerance (tasamuh) (4) balance (tawazun), (5) fair (al-'adli), (6) love (mahabbah), (7) advice (nasihah) and (8) trust (amanah). Generally, studies that are related to syura have been discussed by several previous researchers such as Ahmad, 2006; Shahrul, 2013; Johdi, 2014; Md. Mohiden, 2013; Shahmila, 2013; Ain and Shahril, 2016; Suhana and Ahmad, 2017. Some of the elements in shura that were discussed by them are also discovered to be almost identical and thus used as surveying tools in this study. However, the researcher found that previous researchers did not thoroughly explain the experts' reviewing techniques performed on the validity of the instrument content used. They also did not report the validity test of the quantitative contents using specialized techniques such as CVR. Hence, based on this vulnerability gap, this study focuses more on testing the validity of the content in order to further strengthen the instrumentation by involving several expert panels using the techniques introduced by Lawshe (1975) as Content Validity Ratio (CVR).

\section{Methodology}

\section{Step one: Instrument Development}

Instrument design is produced through three important processes: determining the content domain, content sampling and instrument construction. In this study, the researcher used a Table of Specification Instrument as one of the important procedures and the main guide in instrument development. According Gregory (2006), table of specification basically as an activity which enumerates the information and cognitive tasks on which examinees are to be assessed. For instruments, it is intended to ensure that questionnaire items are not missed and avoid negligence in planning which may cause only a portion of the constructs to be measure. It is also defined as a set of procedures that align the items to be tested through systematic planning (Aijaz, Aziz-un \& Tayyaba, 2014). This method is important to determine the level of objectivity and the validity of the instrument (Najib, 2007). The details required in this table include constructs, variables, questions, traits, items and scales (Sahandri, Laily, Sharifah \& Faizal, 2013). At the same time, literature review on the study was highly important as instructional guidance 
for the instrument (Faizal, Sahandari, Nizam, Mazlini, Noraini, Shafini \& Lajiman, 2014). All of these steps have helped the researcher in determining the specific constructs to form question items based on the identified variables.

\section{Step: Judgment}

This study uses quantitative method through questionnaire survey using one of purposive sampling techniques which is expert sampling as the appraiser. This sampling refers to the selection of expertise through individuals who are specialized in a particular field as samples of the study (Ilker, Sulaiman \& Rukayya, 2016). Selection of appropriate samples is important for the purpose of obtaining positive and accurate information in the process of reviewing all of the items in details. This process is necessary for the purpose of enhancement, suggestions and views to ensure that they cover all contents of the domain that will be tested (Ghazali \& Sufean, 2016; Noraini, 2010). The two main sources involved in the process of testing the validity of this study are comprised of professional panels in the field as well as field experts comprising of population representatives who are relevant to this study. To determine the number of expert panels, Nunnally (1978) has stated that two experts is sufficient. Three experts is sufficient for researches with specific cases such as difficulty in finding experts in the field (Gilbert, \& Susan, 2016). However, according to Lynn (1986), the number of expert panels required in a study that is considered to be sufficient is around five to ten experts. Lawshe (1975) himself has set the number of experts to be at least four panels.

Thus, for this study, researchers have selected eight experts panel to be involved in the validity assessment process. All appointed professionals are those who are directly involved in the field and work in the field (Effendi et al., 2017). According to Rubio, Berg-Weger, Tebb, Lee \& Rauch, (2003), the criteria that should be considered in the selection of expert panels depends on the area of expertise, work experience and the number of publications. There are also must be done on the basic criteria such as specific training, or professional experience on the subject matter (Shrotryia, 2019). In this study, the shortest expert panels' year of experience is 13 years while the longest is 30 years.

\section{Content Validity by Lawshe (1975)}

Generally, there are various evaluation methods have been developed to measure the validity of a quantitative content such as Cohen's Kappa (Cohen, 1960), Aiken (1980) and Fuzzy Delphi Method (Pipino \& Gigch, 1985). However, the method is relatively complex when viewed from the angle of computerized calculations, tends to favor agreement among experts in general, involves several rounds in reaching an agreement among experts and employs the use of over 3 point Likert scale. The justification is, researchers have used the measurement methods of Content Validity Ratio (CVR) introduced by Lawshe (1975) for the purpose of empirically assessing the content validity of the instrument. It has been widely used in various research areas including healthcare, personnel psychology, organizational development, market research and also in the field of education (Wilson, Pan \& Schumsky, 2012).

The advantages of the CVR-inspired method by Lawshe (1975) include uses only three-point scale that refers to (essential, useful but not essential, and not necessary) as a scale of measurement, 
(Gilbert, \& Susan, 2016; Hendryadi, 2014; Ayre \& Scally, 2014) more focused, transparent, easyto-use, requires user-friendly computer calculations, has a critical cut-off schedule value for reference, (Lindell \& Brandt, 1999) and has been recognized internationally (Wilson et al., 2012). Among the previous researchers who have chosen this method in their study are Aksorn and Hadikusomo (2007); Erdem (2009); Ford and Wroten (2006); Arif, Shukran \& Diana (2013); Effendi, Hisyamsani, Normawati \& Zamri, (2017) and Sendjaya, Sarros \& Santora, (2008). In conclusion, quantitative procedures using CVR techniques are not only easy and practical, but also help the analysts to empirically employ all items to maintain items that actually represent the domain in concrete while abolishing items that do not reach a predetermined value.

\section{Content Validity Ratio (CVR)}

Content validity was determined by assessing the level of importance of each item which was built on a three-point scale: (1) Essential (2) Useful but not essential and (3) Not necessary. Responses from all panel experties were combined and the number indicating "essential" for each item was determined (Lawshe, 1975). The calculations were made using the formula CVR = [ne- ( $N / 2)$ ] / ( $/ 2)$. This formula explains that CVR refers to the value of the item being built, ne is the number of expert panels who evaluates the item as essential and $\mathrm{N}$ is the total number of expert panels involved $(N=8)$. According to Lawshe (1975), CVR values are in the range of -1 to +1.00 If the value of $C V R=<0$, it shows that less than half of the panel of experts value the item as "essential". If the value of CVR $=0$, it shows that a part of the group of expert panels involved evaluated the item as being not important while some evaluated it as important "essential". If CVR > 0, the value indicates that over half of the expert panels evaluated the item as essential "essential". The higher the value is from 0 , the higher the legality of the content. Therefore, if CVR $=1.00$ (it is adjusted to .99 for ease manipulation), it is clear that all panels of experts agreed to evaluate the item as "essential" and thus has high content validity. Number of expert panel and minimum value of CVR has been determined by Lawshe (1975) as shown in Table 1.

\section{Table 1.}

Number of expert panel and minimum value for CVR by Lawshe.

\begin{tabular}{llll}
\hline No. of expert & Minimum value & No. of expert & Minimum value \\
\hline & & & \\
$5-7$ & 0.99 & 14 & 0.51 \\
8 & 0.75 & 15 & 0.49 \\
9 & 0.78 & 20 & 0.42 \\
10 & 0.62 & 25 & 0.37 \\
11 & 0.59 & 30 & 0.33 \\
12 & 0.56 & 35 & 0.31 \\
13 & 0.54 & 40 & 0.29 \\
\hline
\end{tabular}

\section{Content Validity Index (CVI)}

We must have to measure objectivity, validity and realibility of that particular research tool to make standardised for all those tools (Patra \& Guha, 2018; Hussin, \& Hafit, (2018); Ofori, Lu, 
(2018). In this study, researcher will be emphasize on the procedure of calculation of content validity in terms of Content Validity Index (CVI) of a self-made questionnaire, which was used to measure level of shura instrument among Islamic education Teachers. After identifying the CVR of each item that needs to be retained, the Content Validity Index (CVI) test should be done by calculating the overall based on the number of items that remains (Lawshe, 1975). The value of $\mathrm{CVI}$ acceptance is different depending on the number of panel experts involved.

\section{Validity Index of Each Item (I-CVIs)}

To obtain content validity index of each item (I-CVIs), the number of those judging the item (rating 3) was divided by the number of content experts. While for relevancy, content validity index can be calculated both for item level (I-CVIs) and the scale-level (S-CVI). In item level, I-CVI is computed as the number of experts giving a (rating 3 ) to the relevancy of each item, divided by the total number of experts. According Zamanzadeh, Ghahramanian, Rassouli, Alavi and Nikanfar (2015), there are two methods for calculating it, One method requires universal agreement among experts (S-CVI/UA), but a less conservative method is averages the item-level CVIs (S-CVI/Ave).

\section{$\mathrm{I}-\mathrm{CVI}=$}

The number of experts giving a rating either 3

The number of experts

It simply involves counting the mean of the CVR, which will total to 0.78 if an expert panel involves 3 or more (Gilbert, \& Susan, 2016; Polit et al., 2007; Karageorgopoulos, 2014). However, for Lynn (1986), for a panel of experts that exceeds six, the CVI value received is greater than 0.78 whereas Tilden, Nelson \& May, (1990) suggested the acceptable CVI value is above .70. Nevertheless, Davis (1992) suggested that CVI values that are greater than .80 to be better and researchers have adopted this designation. Acceptable items if the CVI higher than .79. If it is between .70 and .79 , it requiring modification and if it less than 0.70 , it is unacceptable or eliminated. In this study, the CVI value obtained exceeded 8 for a total of 8 expert panels $(N=8)$.

\section{Results and Discussion}

In the first round judgment, a total of 66 items were constructed in this research instrument to other 8 sub-construct along with the number of item as shown in Table 2. 
INTERNATIONAL JOURNAL OF ACADEMIC RESEARCH IN PROGRESSIVE EDUCATION AND DEVELOPMENT

Vol. 8, No. 4, 2019, E-ISSN: 2226-6348 @ 2019 HRMARS

Table 2: CVR and CVI results for items that need to be remained and eliminated

\begin{tabular}{|l|l|l|l|}
\hline Construct & Total of Item & $\begin{array}{l}\text { Total items of } \\
\text { Eliminated }\end{array}$ & $\begin{array}{l}\text { Total Items of } \\
\text { Remained }\end{array}$ \\
\hline Understanding & 8 & 2 & 6 \\
\hline Cooperation & 8 & 2 & 6 \\
\hline Tolerance & 8 & 2 & 6 \\
\hline Balance & 10 & 4 & 6 \\
\hline Fair & 12 & 6 & 6 \\
\hline Love & 7 & 1 & 6 \\
\hline Advice & 6 & - & 6 \\
\hline Trust & 7 & 1 & 6 \\
\hline $\begin{array}{l}\text { Total } \\
\text { Instrument }\end{array}$ & 66 & 18 & 48 \\
\hline
\end{tabular}

From a set of 66 items, the content validity process identified that 48 items maintained while other 18 items were eliminated. It consists of understanding (tafahum), cooperation (ta'awun), tolerance (tasamuh), balance (tawazun), fair (adil), love, (mahabbah), advice (nasihah) and trust (amanah). All the constructs contain the same number of items (six items). Content validity study revealed that this instrument enjoyed an appropriate level of content validity in CVR value for 8 panels which equals to more than .75. The overall content validity index of the instrument using expert panel agreement approach was high, which was equal or exceeded $.8(C V I=\geq .8)$. The result of Lawshe's Content Validity Ratio (CVR) have shown that the instruments shura employed in this research have a good acceptance value. Meanwhile, according to the expert panel number in this study was 8 , numerical value of the Lawshe table was below 0.75 has been eliminated.

Furthermore, for the second judgment, researcher has been determined that reliability among experts is achieved using the Content Validation Index (CVI). This method takes into account the average level of relevance given by expert panels. To obtain a content validity index for each item, the number of those judging the related item was divided by the number of content experts $(\mathrm{N}=8)$. This process is also carried out to clarify the item of the instrument. The agreement between the judges for the entire instrument was calculated only for relevance according to the overall average agreement approach. Table 6 shows the calculation of CVI for each item according construct successfully was retained. 
INTERNATIONAL JOURNAL OF ACADEMIC RESEARCH IN PROGRESSIVE EDUCATION AND DEVELOPMENT

Vol. 8, No. 4, 2019, E-ISSN: 2226-6348 @ 2019 HRMARS

Table 5: Calculation of I-CVI and S-CVI by two approaches of S-CVI/UA and S-CVI/Ave for dimensions of construct of shura.

\begin{tabular}{|c|c|c|c|c|}
\hline $\begin{array}{l}\text { Dimensions of } \\
\text { construct of shura }\end{array}$ & $\begin{array}{l}\text { Relevant } \\
\text { (rating 3) }\end{array}$ & $\begin{array}{l}\text { Not Relevant } \\
\text { (rating } 1 \text { or } 2 \text { ) }\end{array}$ & I-CVIs* & Interpretation \\
\hline \multicolumn{5}{|c|}{\begin{tabular}{l|l} 
Understanding & \\
\end{tabular}} \\
\hline B1-1. & 8 & 0 & 1 & Excellent \\
\hline B1-2. & 7 & 1 & 0.875 & Excellent \\
\hline B1-4. & 8 & 0 & 1 & Excellent \\
\hline B1-6. & 7 & 1 & 0.875 & Excellent \\
\hline B1-7. & 7 & 1 & 0.875 & Excellent \\
\hline B1-8. & 8 & 0 & 1 & Excellent \\
\hline \multicolumn{5}{|l|}{ Cooperation } \\
\hline B2-1. & 8 & 0 & 1 & Excellent \\
\hline B2-2. & 7 & 1 & 0.875 & Excellent \\
\hline B2-3. & 8 & 0 & 1 & Excellent \\
\hline B2-4. & 8 & 0 & 1 & Excellent \\
\hline B2-5. & 8 & 0 & 1 & Excellent \\
\hline B2-6. & 8 & 0 & 1 & Excellent \\
\hline \multicolumn{5}{|l|}{ Tolerance } \\
\hline B3-1. & 8 & 0 & 1 & Excellent \\
\hline B3-2. & 7 & 1 & 0.875 & Excellent \\
\hline B3-3. & 8 & 0 & 1 & Excellent \\
\hline B3-4. & 7 & 1 & 0.875 & Excellent \\
\hline B3-5. & 8 & 0 & 1 & Excellent \\
\hline B3-6. & 7 & 1 & 0.875 & Excellent \\
\hline \multicolumn{5}{|l|}{ Balance } \\
\hline B4-1. & 7 & 1 & 0.875 & Excellent \\
\hline B4-2. & 8 & 0 & 1 & Excellent \\
\hline B4-3. & 8 & 0 & 1 & Excellent \\
\hline B4-4. & 7 & 1 & 0.875 & Excellent \\
\hline B4-5. & 7 & 1 & 0.875 & Excellent \\
\hline B4-6. & 7 & 1 & 0.875 & Excellent \\
\hline \multicolumn{5}{|l|}{ Fair } \\
\hline B5-1. & 8 & 0 & 1 & Excellent \\
\hline B5-2. & 8 & 0 & 1 & Excellent \\
\hline B5-3. & 8 & 0 & 1 & Excellent \\
\hline B5-4. & 8 & 0 & 1 & Excellent \\
\hline B5-5. & 7 & 1 & 0.875 & Excellent \\
\hline B5-6. & 8 & 0 & 1 & Excellent \\
\hline \multicolumn{5}{|l|}{ Love } \\
\hline B6-1. & 8 & 0 & 1 & Excellent \\
\hline B6-2. & 8 & 0 & 1 & Excellent \\
\hline
\end{tabular}


INTERNATIONAL JOURNAL OF ACADEMIC RESEARCH IN PROGRESSIVE EDUCATION AND DEVELOPMENT

Vol. 8, No. 4, 2019, E-ISSN: 2226-6348@ 2019 HRMARS

\begin{tabular}{|l|l|l|l|l|}
\hline B6-3. & 7 & 1 & 0.875 & Excellent \\
\hline B6-4. & 7 & 1 & 0.875 & Excellent \\
\hline B6-5. & 8 & 0 & 1 & Excellent \\
\hline B6-6. & 8 & 0 & 1 & Excellent \\
\hline Advice & & & & \\
\hline B7-1. & 8 & 0 & 1 & Excellent \\
\hline B7-2. & 8 & 0 & 1 & Excellent \\
\hline B7-3. & 8 & 0 & 1 & Excellent \\
\hline B7-4. & 8 & 0 & 1 & Excellent \\
\hline B7-5. & 8 & 0 & 1 & Excellent \\
\hline B7-6. & 8 & 0 & 1 & Excellent \\
\hline Trust & 8 & & & \\
\hline B8-1. & 8 & 0 & 1 & Excellent \\
\hline B8-2. & 8 & 0 & 1 & Excellent \\
\hline B8-3. & 8 & 0 & 1 & Excellent \\
\hline B8-4. & 8 & 0 & 1 & Excellent \\
\hline B8-5. & 8 & 0 & 1 & Excellent \\
\hline B6-6. & & 0 & 1 & Excellent \\
\hline 48 items & S-CVI/Ave=0.9 & & \\
\hline
\end{tabular}

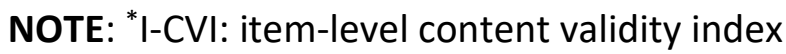

\section{Conclusion}

Content validity in this study involves an objective and a systematic process. The researcher needs to perform two main stages which are designing the instrument and the assessment of the expert panels. Understanding content validity is important for the researcher to ensure that the instrument is suitable to be used as a measuring tool for the study population. As such, this study has contributed to the construction of istruments based on theory and related model in shura with different understanding and more dynamic way. Hence, this article provides a number of implications and research directions for academicians and educations practitioner for investigating the influence of shura on Islamic Education Teachers and their performance in organizational.

\section{Corresponding Author}

Noor Azimah Surip

Faculty of Education, National University of Malaysia

Email: noorazimah1979@gmail.com

\section{References}

Ahmad, S. (2006). Pengamalan ciri-ciri kepimpinan Rasulullah SAW dalam kalangan Guru Pendidikan Islam Daerah Kota Tinggi. Master thesis, Universiti Teknologi Malaysia. (In Malay) 
Aijaz, A., Aziz-un-, N., \& Tayyaba, Z. (2013). Table of specification development and usage: An overview. Interdisciplinary Journal of Contemporary Research in Business, 4(12), 354-361.

Aiken, L. R. (1980). Content validity and reliabity of single items or questionnaires. Educational and Psychological Measurement, 40, 955-959. doi: org/10.1177\%2F001316448004000419.

Cader, A. A. (2017). Islamic principles of conflict management: A model for human resource management. International Journal of Cross Cultural Management, 17(3), 345-363. doi:org/10.1177\%2F1470595817740912.

Aksorn, T., \& Hadikusumo, B. H. W. (2007). Gap analysis approach for construction safety program improvement. Journal of Construction in Developing Countries, 12(1), 77-79.

Al-Buraey, M. A. (1985). Administrative developmet: An Islamic perspective. Kagen Paul International Limited.

Allen, M. J., \& Yen, W. M. (2002). Introduction to measurement theory. Waveland Press.

Anastasi, A., \& Urbina, S. (1997). Psychological testing. Prentice Hall.

Ayre, C., \& Scally, A. (2014). Critical values for Lawshe's content validity ratio: Revisiting the original metods of calculation. Measurement and Evaluation in Counseling and Development, 47(1), 79-86. doi:org/10.1177\%2F0748175613513808

Azhary, M. T. (1992). Negara hukum: Suatu studi tentang prinsip-prinsipnya dilihat dari segi hukum Islam, impimentasinya pada periode negara Madinah dan masa kini. Bulan Bintang. (In malay)

Baker, T. L. (1994). Doing Social Research. New York: McGraw-Hill Inc

Burns, N., \& Grove, S. K. (2005).The practice of nursing research: Conduct, critique \& utilization. Philadelphia: W.B. Saunders Company

Cohen, R. J. (1960). A coefficient of agreement for nominal scales. Educational and Psychological Measurement, 20, 37-46. doi:org/10.1177\%2F001316446002000104

Davis, L. L. (1992). Instrument review: Getting the most from a panel of experts. Applied nursing research, 5(4), 194-197. doi: 10.1111/j.1744-6570.1975.tb01393.x.

Erdem, M. (2009). Effects of learning style profile of team on quality of materials developed in collaborative learning processes. Active Learning in Higher Education, 10, 154-171. doi:org/10.1177\%2F1469787409104902

Esposito, John, L. (2003). Oxford Dictionary of Islam. Oxford Universiti Press.

Ford, J. K., \& Wroten, S. P. (1984). Introducing new methods for conducting training evaluation and for linking training evaluation to program redesign. Personnel Psychology, 37, 651-665. doi:org/10.1111/j.1744-6570.1984.tb00531.x

Frank-Stromberg, M., \& Olsen, S. J. (2004). Instruments for clinical health-care research. Jones and Bartlett Publishers.

Ghazali, D., \& Sufean, H. (2016). Metodologi penyelidikan dalam pendidikan: Amalan dan analisis kajian. Universiti Malaya. (In Malay)

Gilbert, E., \& Susan, P. (2016). Making sense of methods and measurement: Lawshe's Content validity index. Clinical Simulating in Nursing, 12, 530-531. doi: 10.1016/j.ecns.2016.08.002

Gregory, T. (2006) Introduction to research methodology. Onitsha: African, First Publishers.

Hussin, N., \& Hafit, A. (2018). Green Technology: Awareness among Academic Library Employees. International Journal of Academic Research in Progressive Education and Development, 7(3), 161-177. 
INTERNATIONAL JOURNAL OF ACADEMIC RESEARCH IN PROGRESSIVE EDUCATION AND

DEVELOPMENT

Vol. 8, No. 4, 2019, E-ISSN: 2226-6348 @ 2019 HRMARS

Ilker, E., Sulaiman, A. M., \& Rukayya, S. A. (2016). Comparison of convenience sampling and purposive sampling. American Journal of Theoretical and Applied Statistics, 5(1), 1-4. doi: 10.11648/j.ajtas.20160501.11

Kerlinger, F. N. (1986). Foundations of behavioural research. CBS Publishing.

Lawshe, C. (1975). A quantitave approach to content validity. Personnel Psychology, 28(4), 563575. doi: 10.1111/j.1744-6570.1975.tb01393.x

Lynn, M. R. (1986). Determination and quantification of content validity. Nursing Research, 35(6), 382-385.

Md. Mohiden, M. J. (2013). Pengamalan ciri-ciri kepimpinan Rasulullah dalam kalangan Guru Besar. Tesis Sarjana, Universiti Teknologi Malaysia.(In Malay)

Miller, L. A., Loveler, R. L., \& Mclntire, S. A. (2013). Foundations of psychological testing: A practical approach. Sage Publications, United States of America.

Salleh, M. J. (2014). An Analysis of Administrative Staff's Participatory Decision Making through Syura at International Islamic Tertiary Institution. International Journal of Humanities Social Science and Education, 1, 33-39

Najib, M. A. G. (2009). Penyelidikan pendidikan. Universiti Teknologi Malaysia.

Affandi, M. H. (1982). Pengurusan dengan Syura. Universiti Kebangsaan Malaysia.

Ewan, M. E.@ M. M., Hisyamsani, I., Normawati, A. R., \& Ahmad Zamri, K. (2017). Kesahan kandungan pakar instrumen IKBAR bagi pengukuran AQ menggunakan nisbah kesahan kandungan. Proceeding of International Conference on Global Education $V$ (ICGE, V) Padang, Indonesia, 979-997.

Faizal, M. N. L. A., Sahandri, M. G. H., Che Nidzam, C. A., Mazlini, A., Noraini, M. N., Shafini, S., \& Lajiman, J. (2014). An instrument to assess secondary school mathematics teachers' assessment practices in Malaysia. Journal of Teaching and Education, 3(3), $483-492$.

Sahandri, M. G. H., Laily, P., Sharifah, A. H., \& Faizal, M. N. L. A. (2013). Buku panduan pembinaan instrumen "Anda dan kepenggunaan". Emeritus Publications. (In Malay)

Shahrul, M. E. (2013). Amalan Kepimpinan Rasulullah SAW Dalam Kalangan Guru Besar Zon Nusa Jaya, Gelang Patah. Tesis Sarjana, Universiti Teknologi Malaysia. (In Malay)

Murray, T. J., Pipino, L. L., \& Gigch, J. P. (1985). A pilot study of fuzzy set modification of Delphi. Human Systems Management, 5(1), 76-80.

Noraini, I. (2010). Penyelidikan dalam pendidikan. McGraw-Hill. (In Malay)

Nunnally, J. C. (1978). Psychometric theory. McGraw Hill.

Ofori, C. F. Lu, L. (2018). The Evaluation of Internal Audit Functions for Effective Public Sector Administration. A Survey of Accra Metropolitan Assembly, Ghana, International Journal of Academic Research in Accounting, Finance and Management Sciences 8 (2): 19-27.

Ain, N. Y. \& Shahril, M. A. R. (2016). An Islamic view of leadership in quality management. World Aplied Science Journal, 34(4), 448-452.

Patra, A., \& Guha, A. (2018). Content validity index: A simple but significant approach in social science research. ACADEMICIA: An International Multidisciplinary Research Journal, 8(3), 36-42. doi: 10.5958/2249-7137.2018.00020.4 
INTERNATIONAL JOURNAL OF ACADEMIC RESEARCH IN PROGRESSIVE EDUCATION AND

DEVELOPMENT

Vol. 8, No. 4, 2019, E-ISSN: 2226-6348 @ 2019 HRMARS

Polit, D. F., Beck, T., \& Owen, S. V. (2007). Focus on research methods is the CVI an acceptable indicator of content validity? Appraisal and recommendations. Research in Nursing and Health, 30, 459-467. Doi. 10.1002/nur.20199

Rubio, D. M., Berg-Weger, M., S. Tebb, S., Lee, E. S., \& Rauch, S. (2003). Objectifying content validity: conducting a content validity study in social work research. Social Work Research, 27(2), 94-105.

Sendjaya, S., Sarros, J. C., \& Santora, J. C. (2008). Defining and measurement servant leadership behaviour in organizations. Journal of Management Studies, 45, 402-424. doi:org/10.1111/j.1467-6486.2007.00761.x

Shahmila, I. (2013). Amalan kepimpinan Islam menurut Model Al-Ghazali dalam kalangan Guru Besar daerah Kulaijaya, Johor. Tesis Sarjana, Universiti Teknologi Malaysia.(In Malay)

Shrotryia, V. K., \& Dhanda, U. (2019). Content Validity of Assessment Instrument for Employee Engagement. International Journal of Cross Cultural Management, 1-7. doi: $101177 / 2418244018821751$.

Rahayah, S. A. (2008). Inovasi dalam pengukuran dan penilaian pendidikan. Fakulti Pendidikan. Universiti Kebangsaan Malaysia. (In Malay)

KARAGEORGOPOULOS, C. (2014). Information handling manner as main unifying factor in community building. Multilingual Academic Journal of Education and Social Sciences, 2(2), 134-150.

Surip, N. A., Razak, K. A., \& Tamuri, A. H. (2019). Determining Content Validity Instruments Shura elements among Islamic Teachers in Primary Schools. International Journal of Academic Research in Business and Social Sciences, 8(4), 977-988.

Suhana, A. H., \& Ahmad, M. M. (2017). Amalan Syura dalam kalangan kepimpinan berasaskan konsep Amanah. Attarbawiy: Malaysian Journal of Education, 1(2), 93-101. (In Malay)

Ariffin, T. N. (1993). Perspektiffalsafah dan pendidikan di Malaysia. Kuala Lumpur: Dewan Bahasa dan Pustaka. (In Malay)

Tilden, V. P., Nelson, C. A., \& May, B. A. (1990) The IPR Inventory: development and psychometric characteristics. Nursing Research, 39(6), 337-343. doi/10.1097/00006199-19901100000004

Zamanzadeh, V., Ghahramanian, A., Rassouli, M., Abbaszadeh, A., Alavi-Majd, H., \& Nikanfar, A. R. (2015). Design and implementation content validity study: development of an instrument for measuring patient-centered communication. Journal of caring sciences, 4(2), 165. doi.10.15171/jcs.2015.017.

Wilson, F., Pan, W., \& Schumsky, D. (2012). Recalculation of critical values for Lawshe's content validity ratio. Measurement and Evaluation in Counseling and Development, 45(3), 197210. 